Acta vet. scand. 1987, 28, 127-134.

From the Department of Pharmaceutics, Biomedical Center, University of Uppsala, Pharmacia AB, National Veterinary Institute, and Department of Pathology, College of Veterinary Medicine, Swedish University of Agricultural Sciences, Uppsala, Sweden.

\title{
Morphology of the Pig Cornea in Normal Conditions and after Incubation in a Perfusion Apparatus
}

\author{
By Ola Camber, Claes Rehbinder, Tapio Nikkila and Peter Edman
}

\begin{abstract}
Camber O., C. Rehbinder, T. Nikkila and P. Edman: Morphology of the pig cornea in normal conditions and after incubation in a perfusion apparatus. Acta vet. scand. 1987, 28, 127-134. - The fine structure of the pig cornea in normal conditions and after being used in a perfusion apparatus, for $4 \mathrm{~h}$, is described. Earlier reports on the normal morphology of the pig cornea were partly not confirmed. Thus the number of cell layers in the epithelium was found to be 19-23 (a basal cell layer, 4-5 polyhedral cell layers and 14-17 squamous cell layers) compared to earlier reported 6-9 layers.

The mean thickness of normal and perfused corneas were $722 \mu \mathrm{m}$ and $752 \mu \mathrm{m}$ respectively. Normal corneas had a hydration level of $77.2 \%$ and after perfusion $78.5 \%$. The normal morphology and morphological changes due to exposure to perfusion were studied by light and electron microscopy. The differences observed between normal and perfused corneas have to be considered limited, and restricted mainly to the anterior squamous epithelium and the endothelium.

Taken together our results indicate that the corneas used in the apparatus still had functional integrity.
\end{abstract}

pig cornea; in vitro perfusion; corneal thickness; corneal hydration; corneal morphology.

\section{Introduction}

Instead of using living animals to determine the permeability of the cornea to different drugs, in vitro techniques can sometimes be used. Experiments with different in vitro models using rabbit corneas have been reported (Hull et al. 1974, Schoenwald \& Ward 1978, Mosher \& Mikkelson 1979, Francoeur et al. 1983, Schoenwald \& Hung 1983).

The objective of the present investigation was to describe the morphological changes of the normal swine cornea after being used in a perfušion apparatus as described earlier by Camber (1985) and Camber et al. (1986). It was considered suitable to describe the ultrastructure of the normal swine cornea in more detail since this has not been done previously.

\section{Experimental Section \\ Corneas}

Slaughtered pigs (Yorkshire $\mathrm{x}$ Swedish Landrace) were used as donors for the corneas. The pigs were of both sexes, 6 to 7 months old and with slaughter weights be- 
tween 72 and $80 \mathrm{~kg}$. The eyes were obtained from Farmek AB, Uppsala, Sweden. Both eyes from each pig were used. One eye was used in the perfusion apparatus (Camber 1985 ) while the other was used to study the normal morphology or thickness: thus each animal served as its own control.

The control eyes were flushed in situ with Karnowsky solution at the slaughter house. The corneas were excised rapidly and transported to the laboratory in Karnowsky solution. The corresponding eyes to be used in the perfusion apparatus were transported to the laboratory packed on ice. The experimental corneas were removed and mounted in the apparatus. Only corneas from healthy animals were used.

\section{Perfusion apparatus}

The apparatus used to determine the permeability rates of drugs through pig corneas was the same as earlier reported by Camber (1985). The model, made of acrylic plastic, consists of a donor compartment (epithelial side, volume $1 \mathrm{ml}$ ) and a receiving compartment (endothelial side, volume 6 $\mathrm{ml}$ ). Due to the pressure difference between the compartments, the cornea is easily held in position maintaining its shape. Glutathione bicarbonate Ringer's (GBR) solution was used as perfusion medium (Schoenwald \& Hung 1983, Camber 1985). The osmolarity of GBR is $274 \mathrm{mOsm}$ which is close to that of pig aqueous humor, $297 \mathrm{mOsm}$. The fluid in the model was gassed with a mixture of $95 \% \mathrm{O}_{2}$ and $5 \% \mathrm{CO}_{2}$ at a constant temperature of $34-35^{\circ} \mathrm{C}$.

Preparation of corneas for light- and electron microscopy

Corneas from 6 animals were used to study the morphological effects of perfusion. The corneas were fixed in Karnowsky solution for $4 \mathrm{~h}$ immediately after $4 \mathrm{~h}$ perfusion
(Camber 1985), or directly at the slaughterhouse. The cornea samples were stored in the solution for varying times, at a temperature of $+4^{\circ} \mathrm{C}$, before examination. Small pieces, cut from the centre of the corneas, were postfixed for $1 \mathrm{~h}$ in a $1 \% \mathrm{OsO}_{4}$ with $0.1 \mathrm{~mol} / 1$ phosphate before embedding in TAAB 812. After embedding $1 \mu \mathrm{m}$ thick sections were cut and stained with toludine blue, for light microscopy. Sections were prepared on an LKB ultratome, picked up on coated copper grids, stained with uranyl acetate and lead citrate, and examined in a Philips electron microscope EM 420, at 60 $\mathrm{kw}$ and magnifications varying between 500 and 13,500 times. In addition central parts of the corneas were refixed in $10 \%$ buffered formalin, embedded in paraffin, cut in $5 \mu \mathrm{m}$ sections and stained with hematoxylin-eosin for light microscopy. The effect on the corneas of the perfusion apparatus was investigated by means of morphological changes and changes of the thickness in different embedding media.

\section{Thickness and hydration examination}

Corneas from 13 pigs were examined with respect to changes in the corneal thickness and degree of hydration after $4 \mathrm{~h}$ in the perfusion apparatus. Paired corneas were used, one of each pair serving as control. Thickness measurements were done on un-embedded tissues either after $4 \mathrm{~h}$ perfusion or with the controls immediately after excision with a micrometer caliper. The hydration level of the cornea was determined according to Schoenwald \& Hung (1983), after trimming of excess scleral tissue.

\section{Results}

Normal corneas

The influence of different embedding materials, TAAB 812 and paraffin, on corneal thickness was investigated by measuring the 
thickness of the cornea and the corneal cell layers by light and electron microscopy. The cornea was only slightly thicker in paraffin than in TAAB 812 embedded material. The number of epithelial cell layers observed by light microscopy were fewer than by electron microscopy (Fig. 1). Thus, in paraffin and TAAB 812 embedded corneas only 11-12 cell layers could be discerned by light microscopy ( 1 basal cell layer, 4 polyhedral cell layers and 6-7 squamous cell layers) while electron microscopy revealed 19-23 layers of cells ( 1 basal cell layer, 4-5 polyhedral cell layers and 14-17 squamous cell layers). The thickness of the different cell layers, measured by light microscopy and electron microscopy, is shown in Table 1.

Ultrastructural examination of the normal cornea: In the endothelium, the cells and the nuclei were elongated. The cells partly overlapped each other and were sometimes also interdigitated. Zonula occludens (tight junctions), zonula adhaerens and hemidesmosomes were present. Desmosomes were not discernible. Many mitochondria were located around the nucleus and a well developed Golgi apparatus was present. Cisternae of rough endoplasmic reticulum appeared all over the cytoplasm (Fig. 2). In addition a varying number of Pinocytic ve-

Table 1. Thickness of cell layers in normal and perfused cornea.

\begin{tabular}{|c|c|c|c|c|c|}
\hline $\begin{array}{l}\text { Embedding } \\
\text { medium }\end{array}$ & $\begin{array}{l}\text { Examination } \\
\text { method }\end{array}$ & $\begin{array}{l}\text { Tissue/ } \\
\text { Structure }\end{array}$ & $\begin{array}{l}\text { Mean thickness (SD) } \\
\text { of normal and } \\
\text { perfused cornea, } \mu \mathrm{m}\end{array}$ & $\begin{array}{l}\text { Mean difference } \\
(\text { (SD) })^{1)}\end{array}$ & $\begin{array}{l}\text { Number } \\
\text { of paired } \\
\text { corneas }\end{array}$ \\
\hline - & $\begin{array}{l}\text { Micrometer } \\
\text { caliper }\end{array}$ & Cornea & $\begin{array}{l}721.5(52.3) \\
752.3(64.1)\end{array}$ & $30.8(22.6)^{* *}$ & 13 \\
\hline Paraffin & $\begin{array}{l}\text { Light micro- } \\
\text { scopy }\end{array}$ & Epithelium & $\begin{array}{l}55,7(5.1) \\
64.2(8.9)\end{array}$ & $8.5(6.4)^{*}$ & $6^{2)}$ \\
\hline Paraffin & $\begin{array}{l}\text { Light micro- } \\
\text { scopy }\end{array}$ & $\begin{array}{l}\text { Stroma + Descemet's } \\
\text { membrane }\end{array}$ & $\begin{array}{l}641.5(46.6) \\
699.2(35.6)\end{array}$ & $57.7(63.2)$ & \\
\hline Paraffin & $\begin{array}{l}\text { Light micro- } \\
\text { scopy }\end{array}$ & Cornea & $\begin{array}{l}703.8(48.5) \\
768.3(42.0)\end{array}$ & $64.5(67.0)$ & \\
\hline TAAB 812 & $\begin{array}{l}\text { Electron } \\
\text { microscopy }\end{array}$ & Squamous cell layer & $\begin{array}{l}15.2(2.3) \\
17.3(4.4)\end{array}$ & $2.1(3.6)$ & \\
\hline TAAB 812 & $\begin{array}{l}\text { Electron } \\
\text { microscopy }\end{array}$ & Polyhedral cell layer & $\begin{array}{l}24.1(6.2) \\
28.4(7.6)\end{array}$ & $4.3(5.7)$ & \\
\hline TAAB 812 & $\begin{array}{l}\text { Electron } \\
\text { microscopy }\end{array}$ & Basal cell layer & $\begin{array}{l}12.0(3.6) \\
12.7(5.0)\end{array}$ & $0.8(2.2)$ & \\
\hline TAAB 812 & $\begin{array}{l}\text { Electron } \\
\text { microscopy }\end{array}$ & Epithelium & $\begin{array}{l}51.3(7.8) \\
58.4(11.5)\end{array}$ & $7.1(8.2)$ & \\
\hline TAAB 812 & $\begin{array}{l}\text { Electron } \\
\text { microscopy }\end{array}$ & Endothelium & $\begin{array}{l}6.0(0.7) \\
6.7(1.1)\end{array}$ & $0.7(0.7)$ & \\
\hline TAAB 812 & $\begin{array}{l}\text { Electron } \\
\text { microscopy }\end{array}$ & Cornea & $\begin{array}{l}667.7(78.2) \\
819.0(110.0)\end{array}$ & $151.3(92.3)^{*}$ & \\
\hline
\end{tabular}

1) Differences in thickness between normal and perfused corneas tested by Student's $t$ test for paired observations. Significances denoted by: ${ }^{*} \mathrm{p}<0.05,{ }^{* *} \mathrm{p}<0.01$.

2) The 6 pairs of corneas are the same for both paraffin and TAAB 812 embedding. 
sicles were observed. Some corneas had changes in sporadic endothelial cells. These changes varied from slightly degenerative to necrotic. The necrotic cells were overlapped by normally appearing cells.

The lamina limitans posterior (Descemet's membrane) was $12-15 \mu \mathrm{m}$ thick and appeared homogenous. The borderline to the endothelium was much more distinct than that to the stroma (Fig. 3). The substantia propria (stroma) was composed of many sheets of parallel collagen fibrils, the direction of fibrils in one sheet forming approximately right angles with those in the next. Electron dense elongated keratocytes were occasionally observed between the sheets (Fig. 3). They had only a few mitochondria, but a fair amount of rough endoplasmic reticulum.

Bowman's membrane was somewhat uneven, undulated and partly indistinct with the fine collagen fibrils randomly dispersed (Fig. 4). The basal lamina (basement membrane) appeared as a thin condensation, separated from the basal cells by a thin lucent zone (Fig. 4). The epithelium was categorized into 3 types of cells. The basal cells were columnar in shape with elongated nuclei oriented $90^{\circ}$ to the long axis (Figs. 1 and 4). The cell membranes of adjacent cells lay very close and had many interdigitations. There were many small hemidesmosomes toward the basal lamina while few and small desmosomes were seen between the basal cells. The desmosomes were larger and more numerous in connection with polyhedral cells. The cytoplasm contained mitochondria, a fair amount of polyribosomes and a few cisternae of rough endoplasmic reticulum. The main component, however, was a multitude of fine filaments, orientated along the long axis of the cornea, rendering the cytoplasm very opaque.

The 4-5 layers of polyhedral cells were characterized by rounded or oval nuclei and many finger shaped processes interdigitating with surrounding cells (Fig. 5). Adjacent cells were attached by numerous well-developed desmosomes. The mitochondria and the endoplasmic reticulum appeared to be gradually reduced in each subsequent layer. The cytoplasm was packed with fine, randomly orientated filaments.

The remaining 14-17 layers consisted of increasingly flattened squamous cells with flat nuclei (Fig. 6). The granular components were sparsely distributed, as were the cell processes. In the posterior layers, the nuclei were more numerous than in the anterior. Mitochondria were rare and mainly located near the nuclei. The most anterior layers contained only a small number of mitochondria. The cytoplasm was full of filaments with an orientation which tended to parallel the cell surface. The intercellular space between the cells became more narrow in the anterior layers up to the $2-3$ most superficial layers. Cells and the few mitochondria in these superficial layers had sometimes a varying electron density. Often these variations seemed to be located in the most anterior cells. The more homogenous posterior layers were separated from the anterior layers by a very thin distinct electron dense borderline (Fig. 6). This borderline was limited to the anterior cell membrane and a thin rim of the cytoplasm of the outmost intact squamous cells. In the posterior area the cell membranes were undulating and presented a lot of desmosomes. Cells in the most anterior layers were very flat with some vacuoles in the cytoplasm and with distinct filaments. Many connections between cells had separated in the desmosomes, leaving a number of microvilli projecting into the intercellular space (Fig. 6). The surface cells had small microvilli - like protrusions on their free surface. No monocytes, 
Ola Camber, Claes Rehbinder, Tapio Nikkila and Peter Edman: Morphology of the Pig Cornea in Normal Conditions and after Incubation in a Perfusion Apparatus.

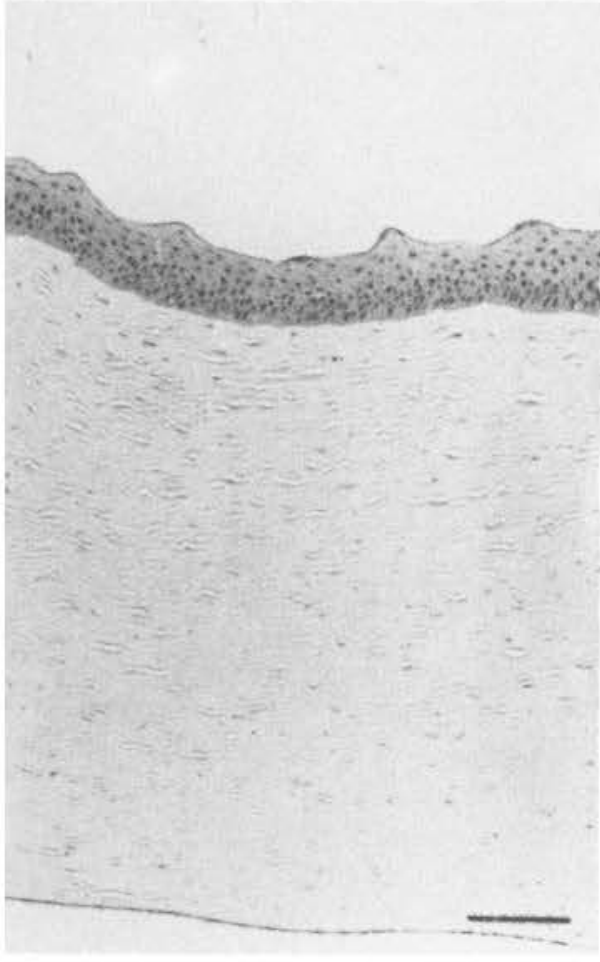

Figure 1. Normal pig cornea. Paraffin embedded. The bar indicates $100 \mu \mathrm{m}$.

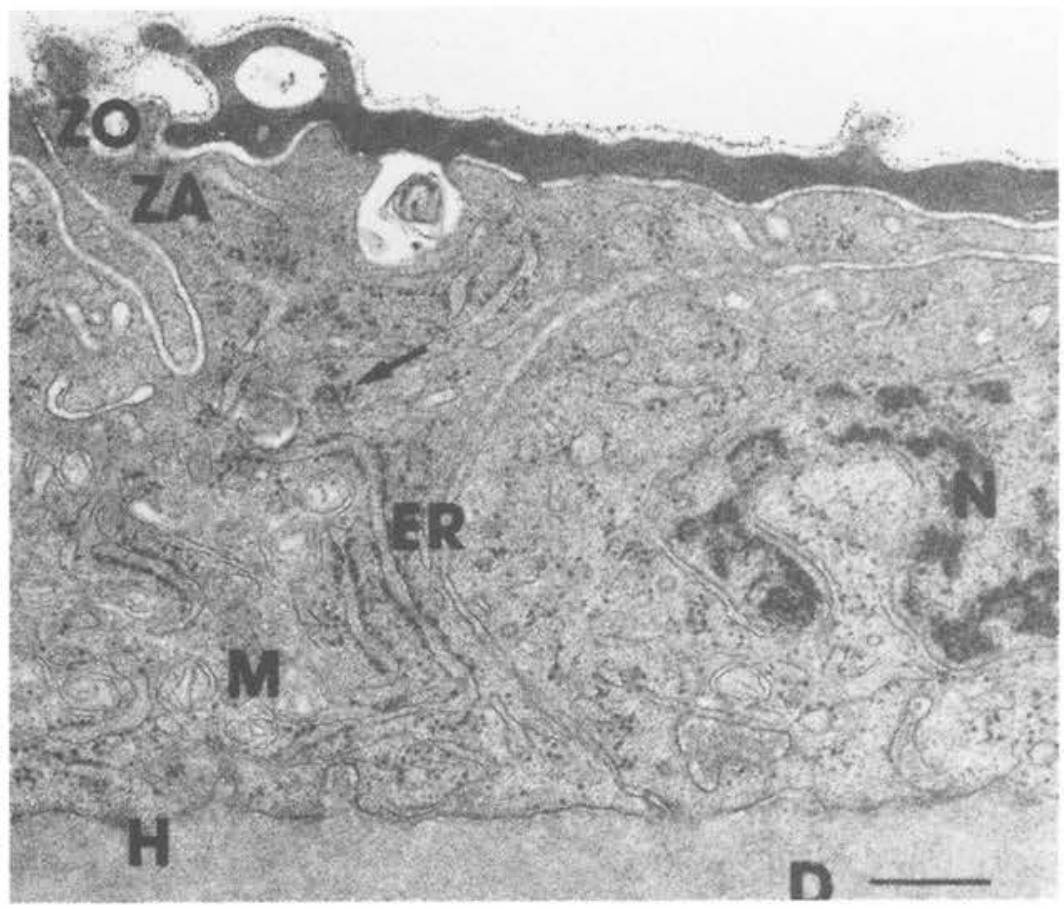

Figure 2. Normal pig cornea. Endothelium and part of Descemet's membrane (D). Nucleus $(\mathrm{N})$, mitochondria $(\mathrm{M})$, rough surfaced endoplasmic reticulum (ER), polyribosomes $(\rightarrow)$, zonula adhaerens (ZA), zonula occludens ( $\mathrm{ZO}$ ), and hemidesmosomes $(\mathrm{H})$ are indicated. Note overlapping degenerating cells. The bar indicates $1 \mu \mathrm{m}$. 


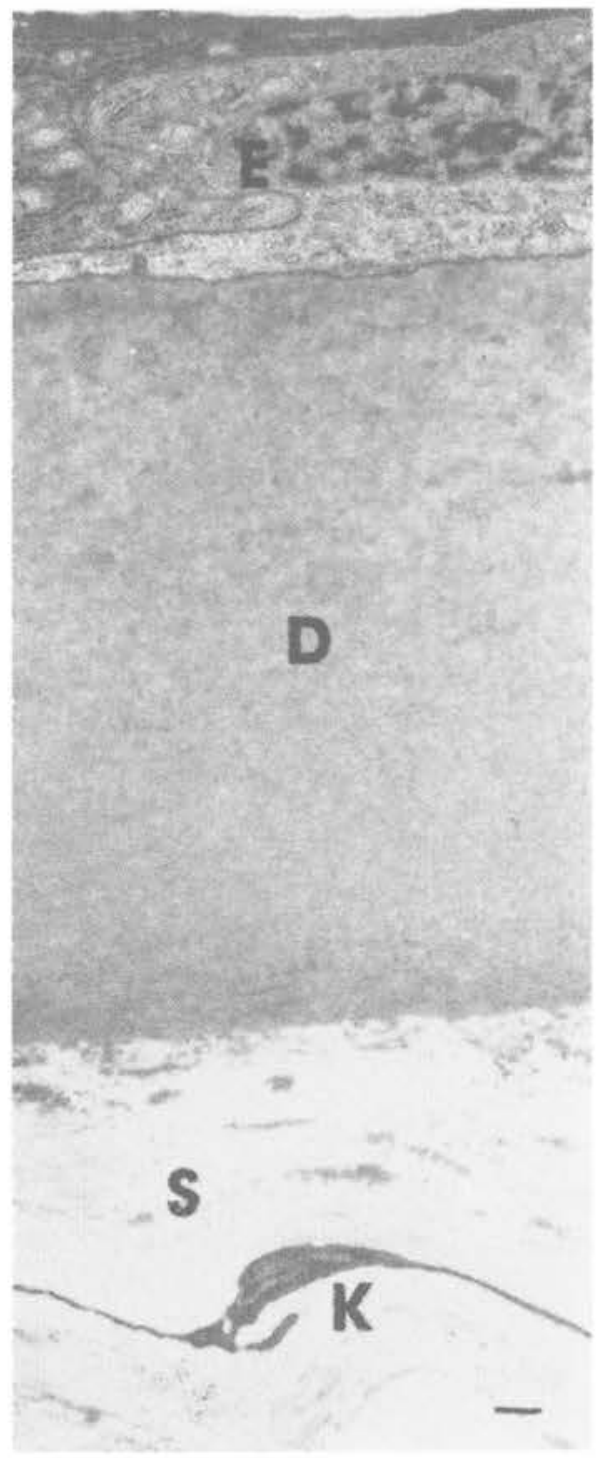

Figure 3. Normal pig cornea. Endothelium (E), Descemet's membrane (D) and part of stroma (S) are indicated. Note the distinct borderline between the endothelium and Descemet's membrane. A less distinct borderline to the stroma is also seen. Note also the keratocytes $(\mathrm{K})$ and the sheets of collagen fibrils in the stroma. The bar indicates $1 \mu \mathrm{m}$. 


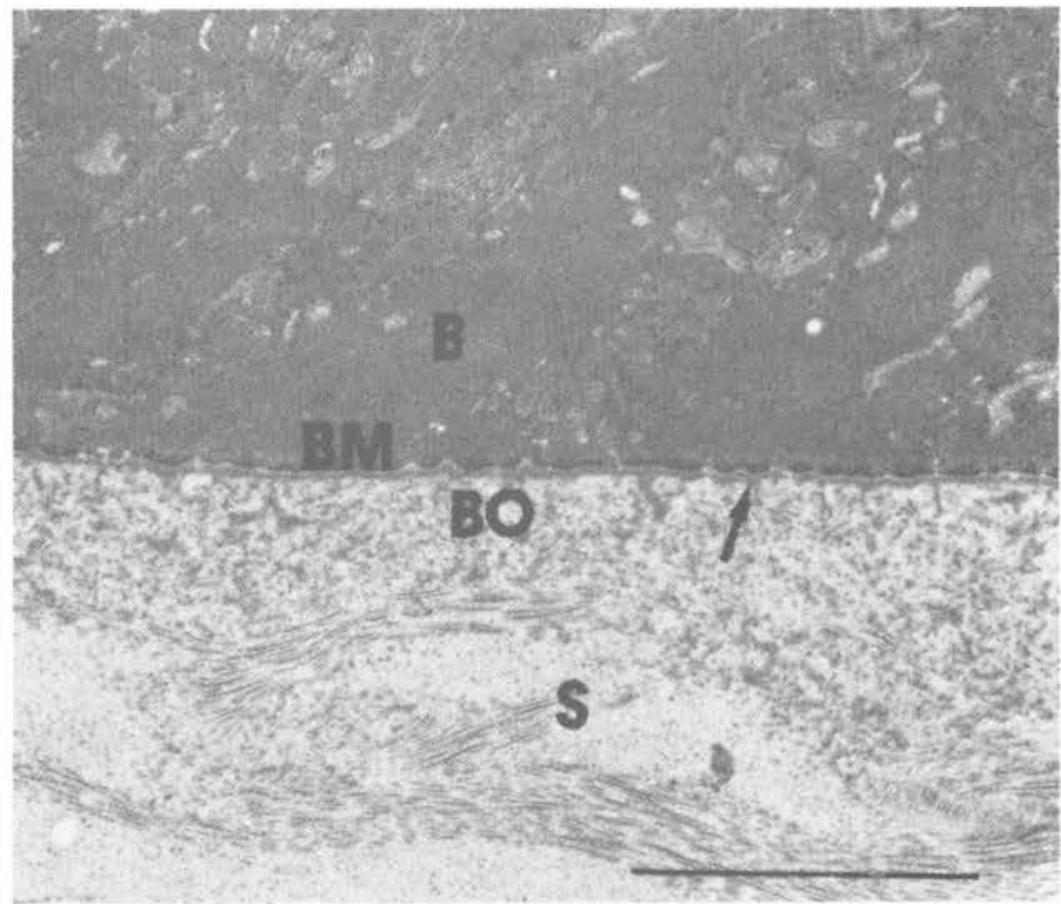

Figure 4. Normal pig cornea. Basal epithelial cells (B), basement membrane (BM), Bowman's membrane (BO) and part of stroma (S). Note the hemidesmosomes $(\rightarrow)$ attaching the epithelium to its basement membrane. The bar indicates $10 \mu \mathrm{m}$.

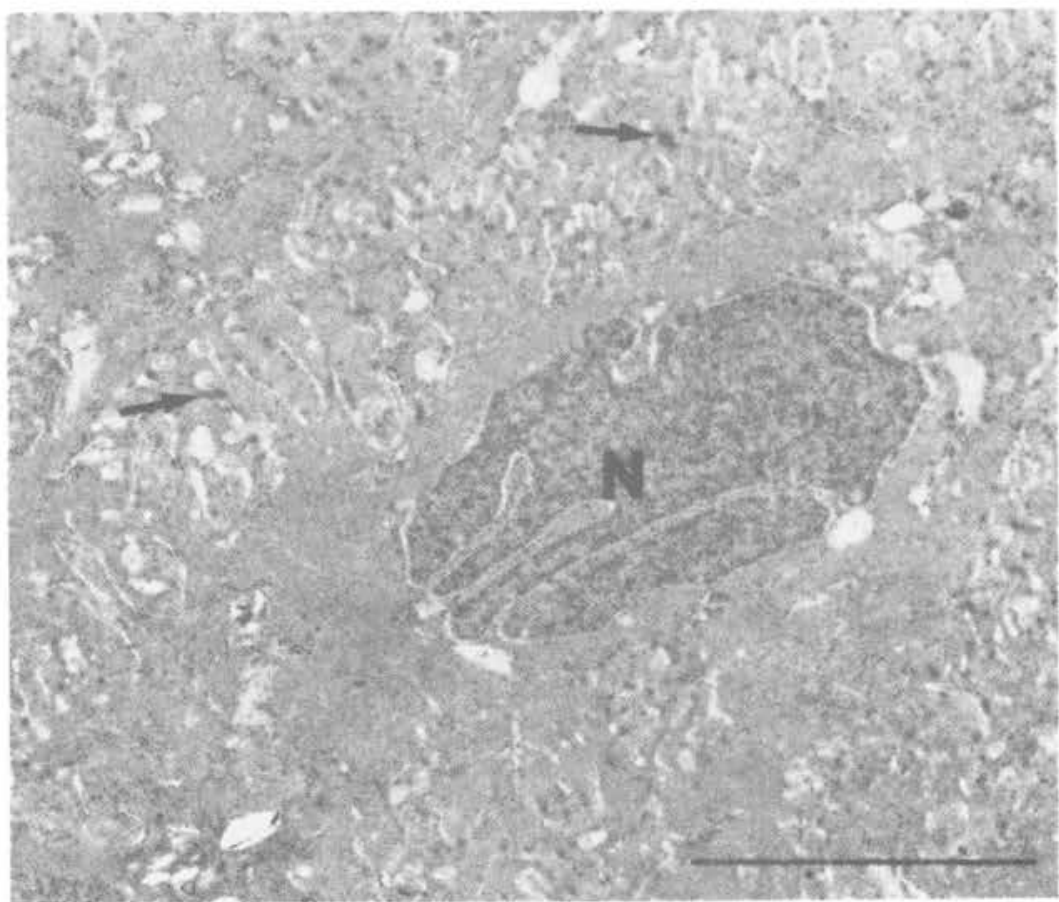

Figure 5. Normal pig cornea. Polyhedral cells. Note the oval and interdigitated nuclei $(\mathrm{N})$ with evenly dispersed chromatin, the frequent interdigitations of the cell membranes and numerous desmosomes $(\rightarrow)$. The bar indicates $10 \mu \mathrm{m}$. 

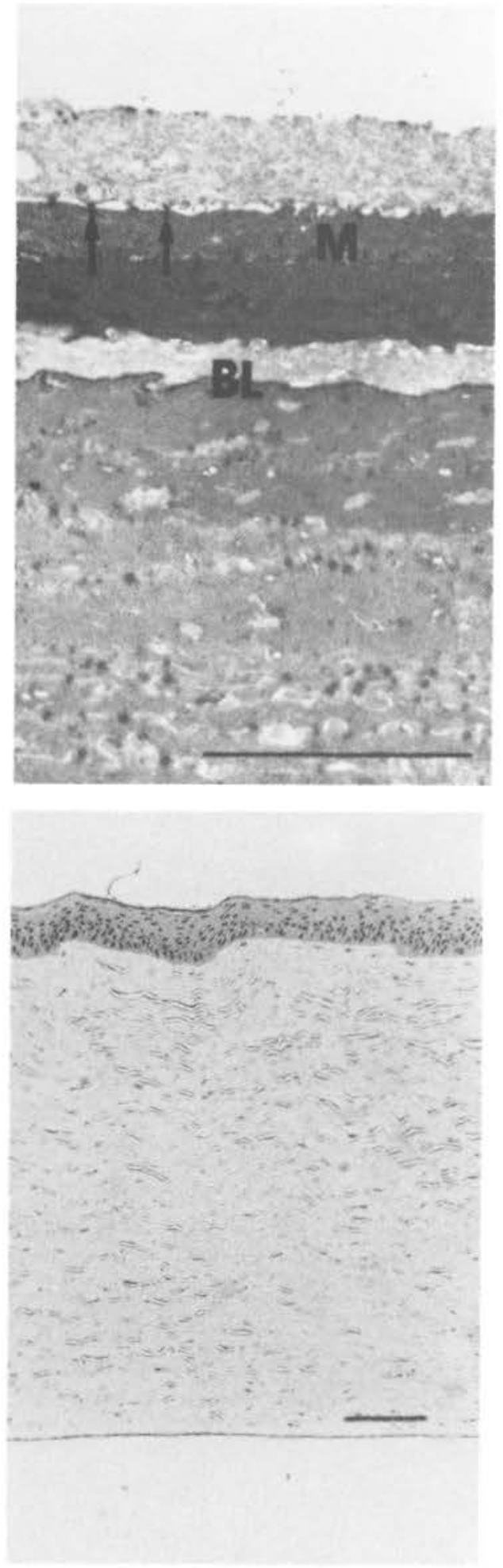

Figure 6. Normal pig cornea. Squamous epithelial cells. Note the thin distinct borderline (BL) and the degenerative changes in the 4-5 anterior cell layers. Note also the separation in the desmosomes $(\rightarrow)$ between the two most superficial layers, leaving a number of microvilli (M) projecting into the intercellular space. The bar indicates $10 \mu \mathrm{m}$.

Figure 7. Perfused pig cornea. Paraffin embedded. The bar indicates $100 \mu \mathrm{m}$. 


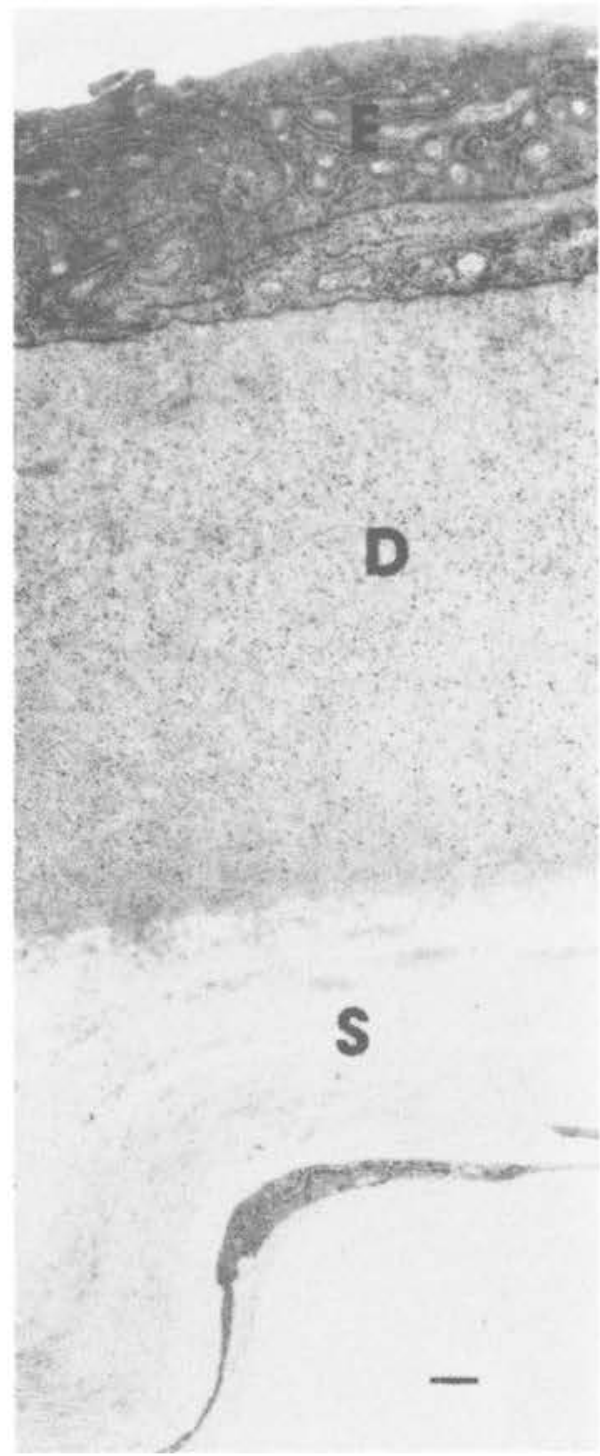

Figure 8. Perfused pig cornea. Endothelium (E), Descemet's membrane (D) and part of the stroma (S). Note the normal ultra structure of Descemet's membrane and the stroma. The bar indicates $1 \mu \mathrm{m}$. 


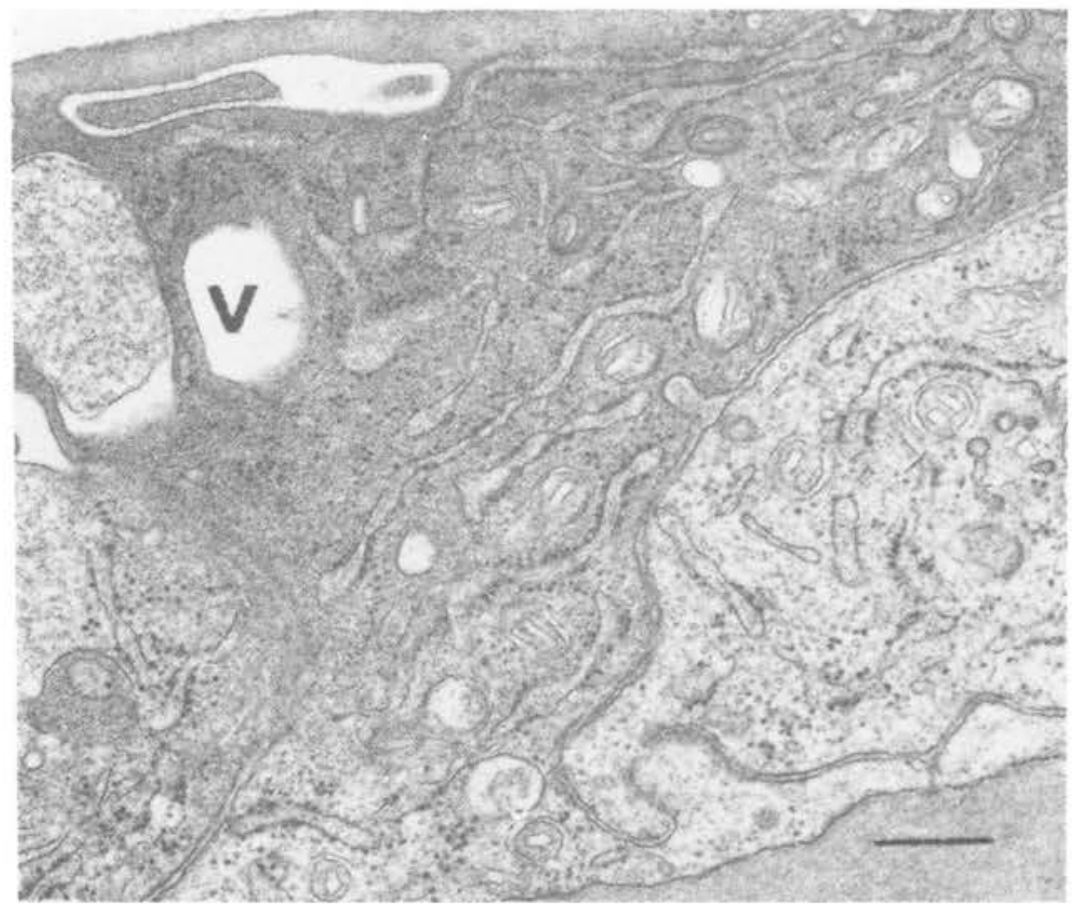

Figure 9. Perfused pig cornea. Endothelium and part of Descemet's membrane. Note the difference in electron density between cells, slightly swollen mitochondria, inter- and intracellular oedema, vacuoles (V) and slightly dilated rough endoplasmic reticulum. The bar indicates $1 \mu \mathrm{m}$. 


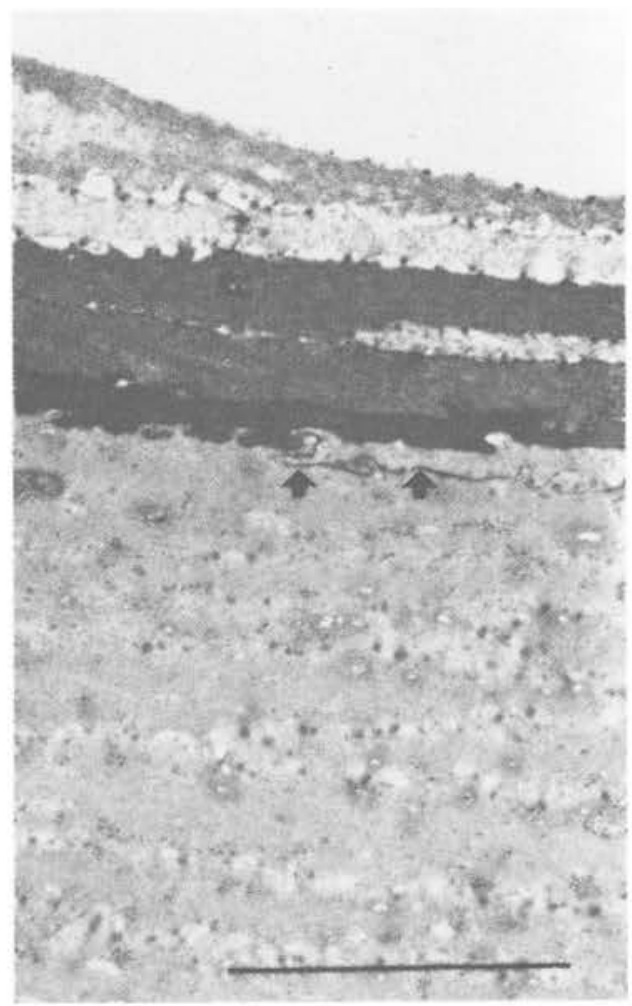

Figure 10. Perfused pig cornea. Squamous epithelium. The difference from the normal pig cornea is small. Note degenerative alterations in the most superficial layers and the distinct borderline between degenerative and normal cells which, however, is partly descending $(\rightarrow)$ between the outer most normal looking cells. The bar indicates $10 \mu \mathrm{m}$. 


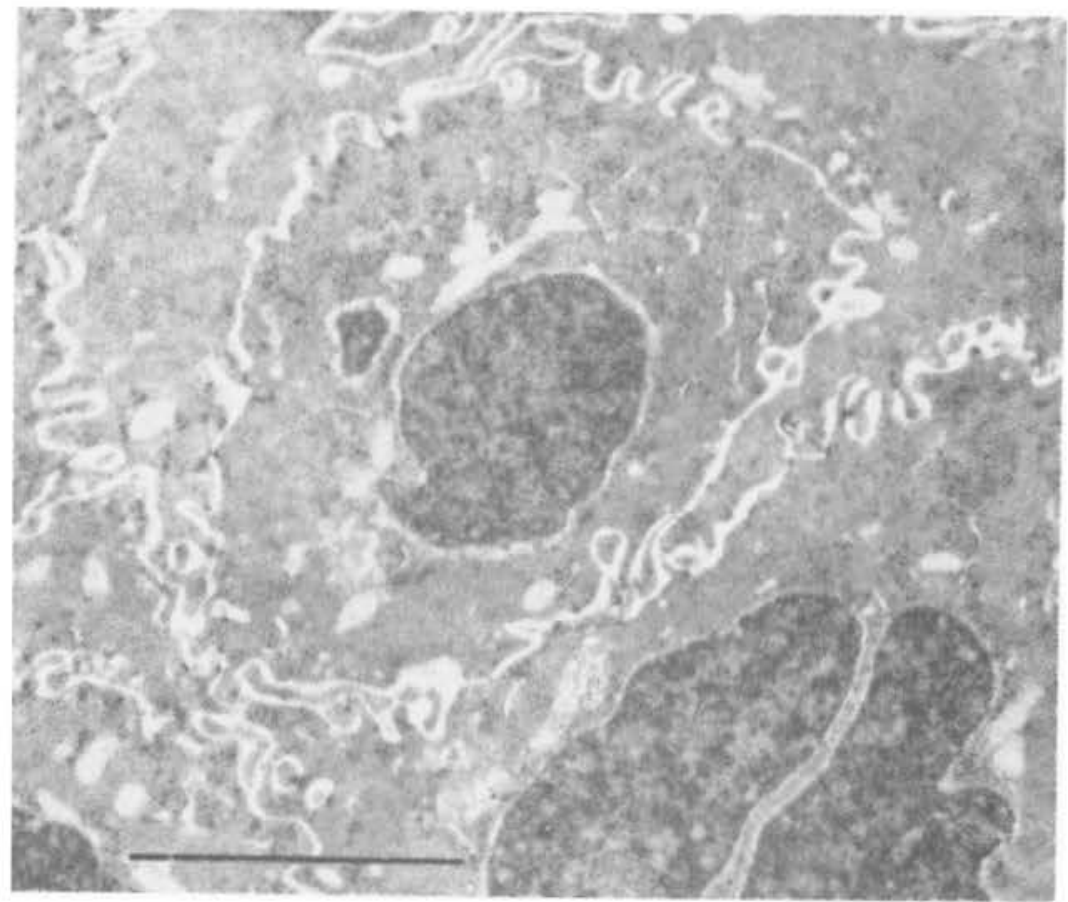

Figure 11. Perfused pig cornea. Polyhedral cells. Note somewhat widened intercellular spaces. The bar indicates $10 \mu \mathrm{m}$.

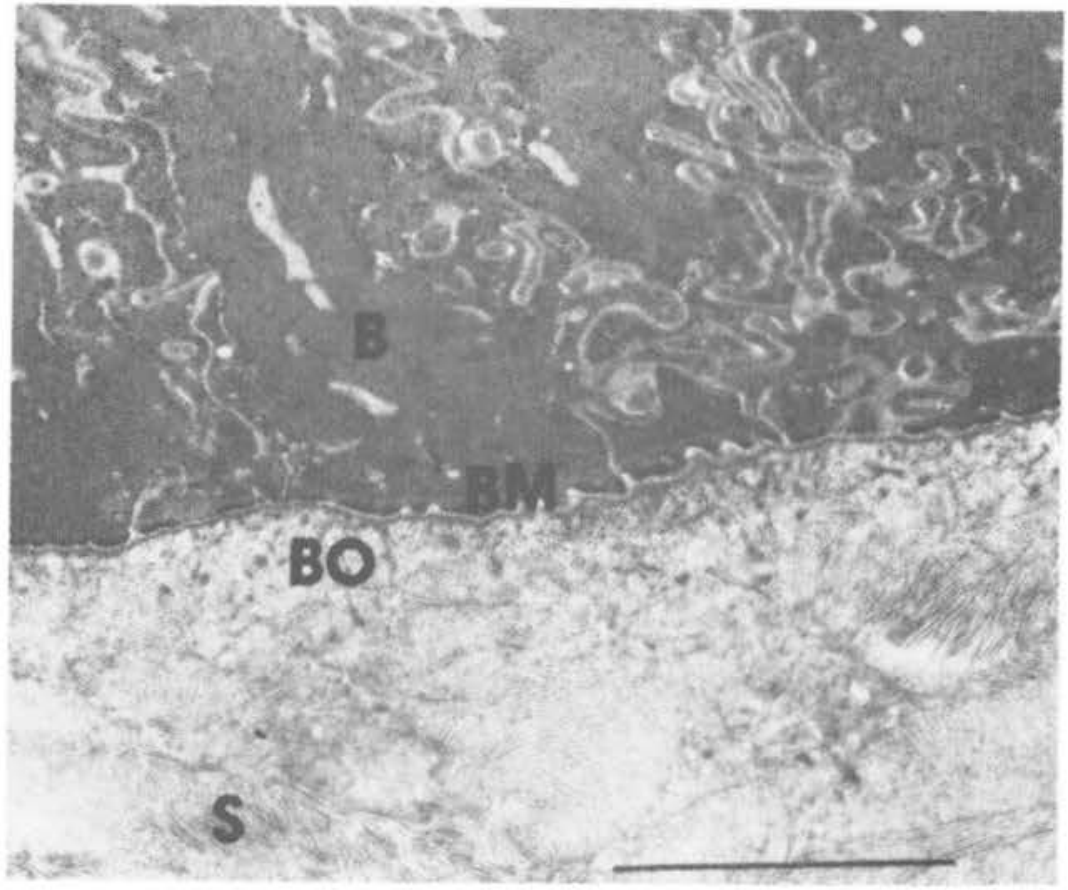

Figure 12. Perfused pig cornea. Basal epithelial cells (B), basement membrane (BM), Bowman's -membrane (BO) and part of the stroma (S). Note somewhat widened intercellular spaces. The bar indicates $10 \mu \mathrm{m}$. 
polymorphonuclear cells or lymphocytes were seen in the specimens.

\section{Perfused corneas}

Table 1 shows thickness changes of the corneal layers and the whole cornea after $4 \mathrm{~h}$ in the perfusion apparatus. A significant thickness increase of the cornea was revealed when using direct measurements with a micrometer caliper or electron microscopy. Light microscopic observations did not show a significant increase of the total cornea (Figs. 1 and 7). The endothelial thickness seemed to be little affected after perfusion.

Ultrastructural examination revealed no alterations in the substantia propria or the adjacent laminae (Fig. 8). The chromatin in the nuclei of the endothelial cells was evenly dispersed. The electron density of the mitochondria was less and in 2 out of 6 corneas they were somewhat swollen (Fig. 9). The endoplasmic reticulum appeared slightly dilated and the number of free ribosomes was increased. Changes in the epithelium were limited to the superficial squamous cell layers (Fig. 10). The number of cell layers with less electron density had increased to about 5 . Cells with varying electron density had increased somewhat and moved the distinct borderline more posteriorly. No widening of the intercellular spaces was observed but the nuclei appeared less electron dense, especially in the anterior part of the epithelium. The polyhedral cells (Fig. 11) revealed no changes compared to the normal corneas except for one case in which they were found to be slightly swollen. The basal cells showed a normal appearance (Fig. 12). The number of cells in the 3 different epithelial layers was not affected by perfusion.

In conclusion, the architecture of the perfused corneas was in most respects similar to that of the normal ones except for the descri- bed limited changes in the epithelium and the endothelium.

\section{Hydration examination}

After $4 \mathrm{~h}$ in the perfusion apparatus the hydration level had risen from $77.2 \pm 0.7 \%$ to $78.5 \pm 0.8 \%$. These results were statistically significant according to a Student's t test for paired observations.

\section{Discussion}

The general structure of the pig cornea is similar to that described for most other species (Jakus 1964, McTigue 1967, Prince et al. 1970, Shively \& Epling 1970, Winqvist \& Rehbinder 1973, Rehbinder et al. 1977, Jakus 1985). Except for the absence of a distinct Bowman's membrane and the proportions of polyhedral and squamous cells, the pig cornea seems to have most characteristics in common with the human cornea (McTigue 1967). A similar pattern concerning Bowman's membrane, as seen in the pig, has been observed in the canine cornea (Shively \& Epling 1970). The electron dense borderline found between degenerating and intact squamous cells has not been found in the literature. However, this investigation does not reveal any morphological entities that make it possible to determine its composition or origin. A connection with the precorneal film (Ehlers 1965) cannot be excluded. An arrangement with few layers of polyhedral cells and many layers of squamous cells has been described for the corneal epithelium of elk (Alces alces L.), roedeer (Capreolus capreolus L.) and reindeer (Rangifer tarandus L.) (Winqvist \& Rehbinder 1973, Rehbinder et al. 1977), whales (Cetacea sp.) and seals (Pinipediae sp.) (Ehlers 1970a, Ehlers 1970b). Prince et al. (1970) reported 1 layer of basal cells, 3-4 layers of polyhedral cells and 2-3 layers of squamous cells in the corneal epithelium of 
pigs while Ehlers (1970a, 1970b) reported a total number of 6-9 of epithelial cell layers. Also, in our study, the number of cell layers discernible appeared less in light microscopy than in electron microscopy but numbered more than reported by Prince et al. (1970) and Ehlers (1970a, 1970b).

The morphological differences observed between normal corneas and those perfused for $4 \mathrm{~h}$ have to be considered limited. They are probably developed continously during the perfusion and restricted mainly to the anterior squamous epithelium and the endothelium. The changes of the epithelium were according to the thickness and hydration measurements in most respects due to an increased hydration level and a limited degeneration of the anterior squamous epithelium. In the perfused corneas as well as in the normal corneas the endothelium showed occasionally necrotic cells and a low pinocytic activity.

In 1 of the 6 corneas degenerative changes were observed, especially in the endothelial cells. It could not be excluded that the reason was either lesions of the cornea in the still living pig or mishandling of the cornea, when removed. The case for lesions of the cornea in the living pig is supported by the bad condition of the paired normal cornea. This finding underlines the importance of a careful investigation of the corneas before they are used and careful sampling and handling during the perfusion experiments.

The differences in thickness between corneas in different embedding materials (Table 1) have been reported earlier by Rehbinder et al. (1973) and may depend on shrinkage or swelling, respectively, during the preparation. The micrometer caliper determinations indicated no difference in thickness between paired normal corneas but a marked variation between animals. Thickness measurements on un-embedded corneas with the micrometer caliper seems to be an easy and reliable method. The low increase in hydration level and the limited histological and ultrastructural changes after $4 \mathrm{~h}$ in the perfusion apparatus support this assumption.

In other investigations, in which corneas have been perfused with GBR solution, small ultrastructural changes (McCarey et al. 1973) and a low thickness increase (McCarey et al. 1973, Riley 1984) were observed and also a low hydration increase (Riley 1984). Experiments have shown that the glutathione apparently plays a great role in the preservation of corneal integrity (McCarey et al. 1973, Ng \& Riley 1980, Riley 1984).

Our studies indicate that if a pig cornea together with a scleral ring is carefully exised to maintain membrane integrity, the cornea will be well preserved in the perfusion apparatus, for at least $4 \mathrm{~h}$, showing only small alterations in thickness, hydration and fine structure. These limited changes should probably be reversible if they occurred in vivo. The results from this paper demonstrate that pig cornea in the described perfusion apparatus maintain standardised conditions and that the perfusion system is reliable.

When comparing permeability data for pilocarpine and hydrocortisone across rabbit and pig cornea, it is shown that the flux of these compounds across pig cornea is somewhat retarded compared to rabbit. This may be due to the thicker corneal epithelium of the pig (Ehlers 1970a). The rabbit cornea is biochemically dissimilar to human corneas (Ehlers 1970a, Cejková \& Bolková 1977, Greiner et al. 1985). Pig, cat and monkey are in this respect more similar. Consequently, this in vitro perfusion apparatus with pig cornea could be suitable to evaluate the permeability of ophthalmic drugs.

Furthermore, as the integrity of the cornea is 
seemingly well preserved it could be possible to study the enzymatic transformation of ophthalmic drugs during their passage through the cornea.

\section{References}

Camber O: An in vitro model for determination of drug permeability through the cornea. Acta Pharm. Suec. 1985, 22, 335-342.

Camber $O$, Edman P, Olsson LI: Permeability of prostaglandin $F_{2 \alpha}$ and prostaglandin $F_{2 \alpha}$ esters across cornea in vitro. Int. J. Pharm. 1986, 29, 259-266.

Cejková J, Bolkova A: A study on alkaline phosphatase in cornea of various animals with special regard to keratocytes. Albrecht v Graefes Arch. Klin. Exp. Ophthalmol. 1977, 204, 209 -214 .

Ehlers $N$ : The precorneal film. Biomicroscopical, histological and chemical investigations. Acta Ophthalmol. (Copenh.) Suppl, 1965, 81, 106.

Ehlers $N$ : Morphology and histochemistry of the corneal epithelium of mammals. Acta Anat. 1970a, 75, 161-198.

Ehlers $N$ : Some comparative studies on the mammalian corneal epithelium. Acta Ophthalmol. 1970b, 48, 821-828.

Francoeur $M$, Ahmed I, Sitek $S$, Patton TF: Age-related differences in ophthalmic drug disposition III. Corneal permeability of pilocarpine in rabbits. Int. J. Pharm. 1983, 16, 203-213.

Greiner JV, Lass JH, Glonek T: Interspecies differences in mammalian corneal metabolites: a phosphorus-31 nuclear magnetic resonance study. ARVO meeting, Sarasota, Florida 1985, p. 181.

Hull DS, Hine JE, Edelhauser HF, Hyndiuk RA: Permeability of the isolated rabbit cornea to corticosteroids. Invest. Ophthalmol. 1974, 13, 457-459.

Jakus MA: Ocular Fine Structure. Selected Electron Micrographs. Little, Brown \& Co., Boston 1964.
Jakus MA: Studies on the cornea. I. The fine structure of the rat cornea. Amer. J. Ophthalmol. 1985, 38, 40-53.

McCarey BE, Edelhauser $H F$, Van Horn DL: Functional and structural changes in the corneal endothelium during in vitro perfusion. Invest. Ophthalmol. 1973, 12, 410-417.

McTigue JW: The human cornea: A light and electron microscopic study of the normal cornea and its alterations in various dystrophies. Tr. Amer. Ophthalmol. Soc. 1967, 65, 529603.

Mosher GL, Mikkelson TJ: Permeability of the $\mathrm{n}$-alkyl p-aminobenzoate esters across the isolated corneal membrane of the rabbit. Int. J. Pharm. 1979, 2, 239-243.

$\mathrm{Ng} M C$, Riley $M V$ : Relation of intracellular levels and redox state of glutathione to endothelial function in the rabbit cornea. Exp. Eye Res. 1980, 30, 511-517.

Prince JH, Diesem CD, Eglitis I, Ruskell GL: Anatomy and Histology of the Eye and Orbit in Domestic Animals: Charles C. Thomas, Springfield 1970, p. 217.

Rehbinder $C$, Winqvist $G$, Roos $C$ : Structure of the cornea in some cervidae. Acta vet. scand. 1977, 18, 152-158.

Riley $M V$ : A role for glutathione and glutathione reductase in control of corneal hydration. Exp. Eye Res. 1984, 39, 751-758.

Schoenwald RD, Hung HS: Corneal penetration behaviour of $\beta$-blocking agents I: Physicochemical factors. J. Pharm. Sci. 1983, 72, 1266-1272.

Schoenwald RD, Ward RL: Relationship between steroid permeability across excised rabbit cornea and octanol - water partition coefficients. J. Pharm. Sci. 1978, 67, 786-788.

Shively NJ, Epling GP: Fine structure of the canine eye: Cornea. Amer. J. Vet. Res. 1970, 31, 713-722.

Winqvist $G$, Rehbinder $C$ : Fine structure of the reindeer cornea in normal conditions and in keratitis. Acta vet. scand. 1973, 14, 292-300. 


\begin{abstract}
Sammanfattning
Morfologin hos grisens hornhinna under normala förhållanden och efter inkubation i en perfusionsapparat.

Ultrastrukturen hos grisens normala cornea och förändringar $\mathrm{i}$ samband med 4 tim $\mathrm{i}$ en perfusionsapparat redovisades. Tidigare studier av grishornhinnans morfologi kunde delvis inte styrkas. Således var antalet cellager $\mathrm{i}$ epitelet 19-23 (1 lager basalceller, 4-5 lager polyedriska celler och 14-17 lager plattepitel celler) jämfört med tidigare rapporterade 6-9 lager.

Medeltjockleken hos normal hornhinna bestäm-
\end{abstract}

des till $722 \mu \mathrm{m}$ och hos perfunderad till $752 \mu \mathrm{m}$. Den normala hornhinnans hydratiseringsgrad var $77.2 \%$ och efter perfusion $78.5 \%$. Den normala morfologin och morfologiska förändringar beroende av perfusion studerades med ljus- och elektronmikroskopi. De observerade skillnaderna mellan normala och perfunderade hornhinnor kan betraktas som små och huvudsakligen begränsade till de yttre plattepitel cellerna och endotelet. Sammantaget så visar resultaten att grishornhinnans morfologi är i stort sett bibehållen efter 4 tim perfusion.

(Received November 20, 1986).

Reprints may be requested from: Ola Camber, Pharmacia AB, S-75182 Uppsala, Sweden. 